\title{
The Role of Legal Reasoning in the Conduct of Human Affairs
}

\author{
$1 *$ Henry A. Akuchie, Rsf, Mife. \\ Ibrahim Badamasi Babangida University, Lapai, Niger State, Nigeria
}

\begin{abstract}
Legal reasoning is part of the judicial process that revolves around what judges and courts do in deciding or adjudicating cases. The judicial process traditionally recognizes four major themes namely: legal reasoning, judicial discretion, precedent and statutory interpretation. This article focuses on legal reasoning. A judge makes a judgment about human affairs. There is a claim that he reasons about it and not many are prepared to accept such a claim; hence the interrogation: does reason actually play a role in human affairs? Opinions are divided between those who think that reason plays a role in human affairs and those who berate the role of reason and extol that of sentiment.
\end{abstract}

Keywords: Logic, Argumentation, Inductive, Persuasion, Inference, Morality and Intellect.

DOI: $10.7176 / \mathrm{JLPG} / 87-08$

Publication date:July $31^{\text {st }} 2019$

\section{INTRODUCTION}

\subsection{The Denial of the Role of Reason in Human Affairs}

There are those who think that the role of reason is not significant in human affairs. One of them is Thomas Hobbes, who believes that men are fundamentally selfish and are ruled by emotions. ${ }^{2}$ Moral judgments are based on a person's feeling; hence, Hobbes arrives at the conclusion that right and wrong, good and bad are not in the nature of things but passions of the mind. ${ }^{3}$ Bernard Mandeville does not think that men have always been social. According to him, morality is a deliberate intervention of the society, a product of "some victory great or small over untaught

nature". Mandeville insists that it is in men's nature to cover their failings and be impartial judges of themselves. ${ }^{4}$ David Hume agrees with the view that morality is a societal intervention, for its own use. He accepts, to a large extent, the influence of self-love in our acting. He argues that reason operates only upon given premises against which we ascertain the conclusion that follow from them: example, $2+2=4$ or A owes B N20 therefore A has to pay B N20. This conclusion only has practical force for A; it does not mean that everyone has to pay his or her debts. Such judgments which imply 'ought' are not conclusions of reason according to Hume; hence he claims that no set of descriptive statements entails prescriptive statements. ${ }^{5}$

According to him, reason helps us to discover primary qualities like figure, but it bears no hand in a constant conjunction of passing from one impression to an idea. ${ }^{6}$ It is opposed to all the ideas that spring from an imagination. ${ }^{7}$ Reason can never advise us as to the following of the fancy of our imagination. ${ }^{8}$ For one to be moved into action, passion or sentiment has to be in place, thus morals excite passions; and produce or prevent actions. Reason of itself is utterly important in this particular. The rules of morality, therefore, are not conclusions of our reason. ${ }^{9}$ It is Hume's belief that reason is not a species that causes or motivates action. ${ }^{10}$ It can never prevent volition, and "is and only ought to be the slave of passions." 11

\subsection{The Affirmation of the Role of Reason in Human Affairs}

On the one hand, reason has always been regarded as having a hand in directing human affairs or the state. In both the Timaeus and Critias Platonic dialogues there are accounts of an imaginary world - Atlantis - to which Plato has interest in the planning and construction of its capital.

Plato is preoccupied with considerations of what an ideal state should be to which actual states must conform, and the true statesman must know the reign of justice and learn what life in the state ought to be;

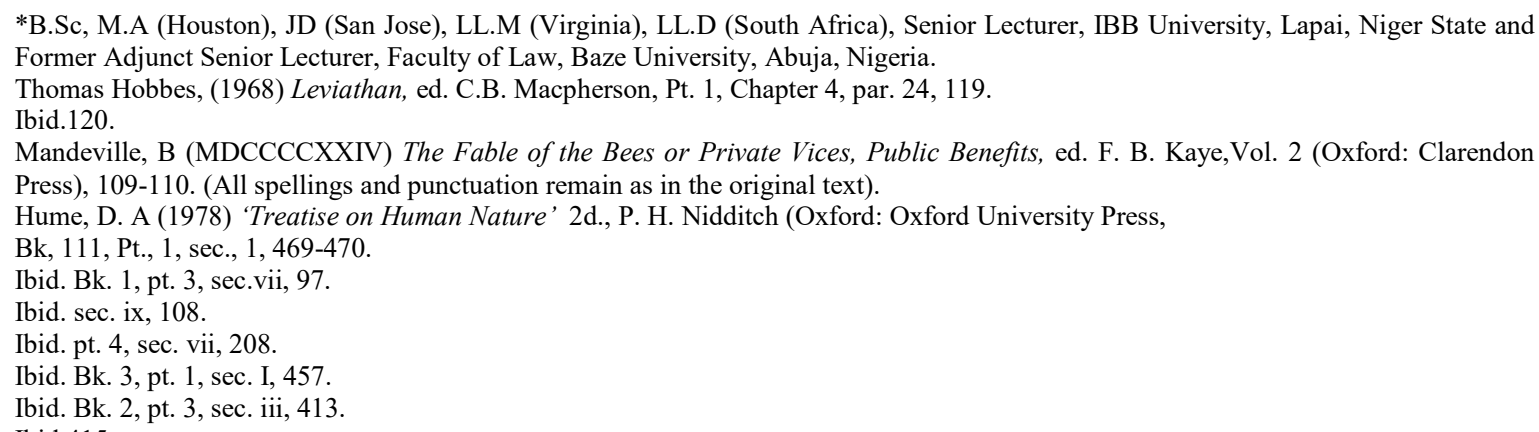


otherwise, he ruins himself and the state. Experience taught Plato to turn his back on an active political life. ${ }^{1}$ To emerge from such a political morass, he says, is when, "either the stock of those who rightly and genuinely follow philosophy acquire political authority, or else the class who have political control be led by some dispensation of providence to become real philosophers. ${ }^{2}$ In Book 4 of the Republic, (439a-443e), Plato gives the doctrine of the tripartite nature of the soul, a doctrine which also recurs in Timeaus (69d6-70a 7 ). The soul has three parts, namely: the rational, the courageous/spirited, and the appetitive parts.

The rational part (the highest element) distinguishes humans from brutes. The other parts are perishable: the spirited part is nobler and in humans it is akin to moral courage. The appetitive part refers to bodily desires. In the Phaedrus, Plato compares the rational element to a charioteer, and the spirited and appetitive elements to two horses. ${ }^{3}$ One can discern Plato's ethical interest as he insists on the rightness of the rational element to rule, to act as the charioteer. Functions in the state are likened to the division of the nature of the soul. There is justice when all the parts of the soul are harmonized.

The wisdom of the state resides in the small class of rulers, the courage of the state in the auxiliaries, and the temperance of the state consists in subordination of the ruled to the ruler. Thus, justice in the state is founded on one doing what one is most suited to do without interfering in the business of the other class. ${ }^{4}$ For Aristotle, thought is a distinctively human activity as a character or function of the soul, and it sets humans apart and above other animals; the intellect is the divine within humans, thus the excellences most properly human are the intellectual excellences. ${ }^{5}$ Therefore, eudemonia or human flourishing primarily consists of an activity in accordance with intellectual excellences. ${ }^{6}$ Aristotle speculates that happiness is the chief good understood in an inquiry into the background of the function of humans. ${ }^{7} \mathrm{He}$ implies that intellectual pursuit constitutes happiness for humans and makes them flourish. ${ }^{8}$ The intellectual virtues will widen the horizon of people's visions. And this explains why societies should take pride in developing the intellectual capabilities of their citizens. A sound intellectual life is itself sufficient to constitute a happy life. One appreciates the high priority placed on education or institutions in the state, by Aristotle, where characters are molded: moral and physical abilities are developed in order to produce sound minds fit for the state. Thomas Aquinas affirms the role of reason in action. Human action is the combined effect of the intellect and the will; hence law is an ordinance of reason promulgated by one who has care for the community. ${ }^{9}$

Ralph Cudworth contends that morality is demonstrable; that moral good and evil, just and unjust, honesty and dishonesty are not arbitrary. Things are fundamentally what they are by nature. There is a rationality embodied in the nature of things. Morality, therefore, is not built on conventions or arbitrary principles. ${ }^{10}$ In his Treatise on Morality, Malebranche asserts that reason is the word or wisdom of God himself. Man is a rational creature, and through reason he can discover relations and propositions. ${ }^{11}$ For Malebranche, reason discovers relations of ideas as well as that of morality, which means therefore that morality and human affairs can be demonstrated. In his opinion, there is a rational law to which moral conduct must conform. So just or unjust are not mere sentiments of an observer.

Anthony Earl of Shaftesbury talks of public affections (which are objective) men have and which tend for good of society. The mind, with its eyes and ears, discerns proportions, distinguishes and scans each sentiment or thought that comes before it. "Thus, it feels the soft and harsh, the agreeable and disagreeable, in affections, and finds a foul and fair, in them", says Shaftesbury. Our mind discerns differences in the perspectives represented to it, and then takes sides with what is good as worthy towards the public, and this Shaftesbury judges as virtuous acts, for the assessment of virtuous actions comes from reflection. ${ }^{12}$ Thomas Reid does not accept Hume's reduction of source of action to mere impulse or animal reactions. One of the first principles of operation of the mind is reason. ${ }^{13}$ Reid believes that reason cannot be ignored in human conduct. He writes:

A being endowed with animal principles of action only, may be capable of being

trained to certain purposes by discipline, as we can see many brute-animals are, but would be altogether incapable of being governed by law. The subject of law

Plato, Epistle Letter VII, 325d-369a2

Ibid., 326b1-4.

Plato, Phaedrus, 246a6ff

Ibid., 433a1ff; 443c6-8.

Aristotle, Nicomachean Ethics, Bk, 1, 1098a6-15

Barnes, J (1982) 'Aristotle' (Oxford: Oxford University Press), 79.

Aristotle, Nicomachean Ethics, Bk, 1, 1097a25

Ibid. Bk. 1, 1098a6-15.

Thomas Aquinas, Summa Theologica, 1-11, q.91a1.

Schneewind, J. B (1990) ed., 'Moral Philosophy from Montaigne to Kent: An Antology' (Cambridge: Cambridge University Press), Vol. $1,277-279$.

Ibid. Vol. 1, 259.

Shaftesbury, A. E (MDCCXC) 'Characters of Men, Manners, Opinions, Times with a Collection of Letters', Vol. 2 (Legrand), 23.

Reid, T (1983) 'Inquiry and Essays eds. Ronald E. Beanblossom and Keith Lehrer (Indianapolis: Hackett Publishing Company, Inc.), 152. 
must have the conception of a general rule of conduct, which, without some degree of reason, he cannot have. He must likewise have a sufficient inducement to obey the law, even when his strongest animal desires draw him to the contrary way. This inducement may be a sense of interest, or a sense of duty, or both concurring. These are the only principles am able to conceive, which can reasonably induce a man to regulate all his actions according to a certain general rule or law. They may therefore be justly called the rational principles of action, since they can have no place but in a being endowed with reason, and since it is by them only that a man is capable either of political or moral government. Without them human life will be like a ship at sea without hands, left to be carried by winds and tides as they happen. It belongs to the rational part of our nature to intend a certain port, at the end of the voyage of life; to take advantage of the winds and tides when they are favorable, and to bear up against them when they are unfavorable. ${ }^{l}$

Our rationality is manifested, according to Reid, in our adherence to general principles; for example, no acts of violence ought to be perpetrated on human beings save in certain justifying or excusing circumstances.

Reid seems to have answered Hume well; it is possible that Hume would claim that the so-called circumstances that manifest our rationality might be dispositions of our sentiments and wills in shaping our social environment. John Finnis has noted Hume's inability to realize that reason plays a great role in human affairs. ${ }^{2}$ People are motivated by what they know. That which the intellect considers as true, the will goes for it.

\subsection{But Does Reason Feature in Justifying Decisions in Law?}

There is little doubt that reason plays a part in human affairs. The major problem however as articulated by Neil MacCormick is: "how far is the determination of order in human affairs a matter of reason?" 3 MacCormick believes that:

Any mode of evaluating an argument must involve, depend on, or presuppose, some ultimate premises, which are not themselves provable, demonstrable, or conformable in terms of further or ulterior reasons. In that sense, our ultimate normative premises are not reasons, not the product of a chain of logical reasoning. ${ }^{4}$

However, to claim that our ultimate normative premises are not reasoned does not mean, "no reasons at all can be given for adhering to such ultimate premises - 'principles' - as grounds for action and judgment. But the reasons, which can be given, are not in their nature conclusive, nor equally convincing to everyone. Honest and reasonable people can and do differ even upon ultimate matters of principle, each having reasons which seem to him or her good for the view to which he or she adheres." 5

Certainly, our predispositions of will or affective natures are determinant factors in our assent to some or another normative principle; it is also true that the will goes for what the intellect proposes to it as true: therefore, both intellect (reason) and will combine in the production of human action. Human beings are not matter in motion as Hobbes believed or webs of flitting impressions subject to the laws of Newtonian physics as Hume conjectured. In other words, in addition to being acted upon, human beings act upon things or create changes in their environment. Such changes, besides being caused by natural events, can be explained in terms of reasons for which the agent acted. Therefore, the behaviorists' explanation of human action does not do justice to moral subjects who act for reasons in terms of intention explainable as constituting their plan of action. Against this background, MacCormick writes:

Whatever the basis of our adherence to such principles of conduct as we take to be ultimate, it is the case that for human beings they belong among the category of reasons for acting and reasons for judgment about and critical or approbative reactions to other's acting. What is more, because they are not ad hoc or ad hominem but universal in their tenor and their reference to human beings as such, or categories of human beings, there is indeed ------ good grounds for distinguishing them from simple emotional or animal reactions to immediate circumstances, and even from what Hume called 'calm emotions. ${ }^{6}$

There is a plan when humans act; and the rational pattern imposed on humans' actions indicates that humans are not objects of purely experimental observation/schemata:

Ibid.314.

Finnis, J (1980) 'Natural Law and Natural Rights'. Oxford: Oxford University Press.

MacCormick, N (1978) 'Legal Reasoning and Legal Theory' (Oxford: Clarendon Press Oxford), 5.

Ibid.

Ibid.

Ibid. 6 
The attempt to articulate principles for action belongs in the realm of reasoning concerning the practical affairs of life; it is concerned with the guidance of decisions, judgments, appraisals, and all the rest of it. That is not to say that all our reasons for acting are principled, not to say that people do not often act in a merely impulsive way. But to the extent that we do, sometimes at least, act and judge upon principle rather than for some ad hoc reason, it is our rational as well as indeed our affective nature, that is manifested in such acting. ${ }^{.}$

There is a reason, a pattern in our acting. However, the point is, in reference to the making and justifying of decisions in law, is there a reason? If there is a reason, to put it in jurist terms, what is the nature of legal argumentation as manifested in the public process of litigation and adjudication upon disputed matters of law? What kind of reason, therefore, is it?

\subsection{What is the Nature of Legal Argument?}

It is a widely held assumption that lawyers have a particular method of reasoning called legal reasoning. And people say it is logical. This assumption has not gone undisputed. The first step in the claimed so-called legal reasoning is to examine whether it is logical. What is it to say that reasoning is logical? Logic is "the study of methods and principles used to distinguish good (correct) reasoning from bad (incorrect) reasoning." 2 logician is primarily concerned with correctness of the completed process of reasoning. He/she will always ask whether the premises underscored in a given argument provide good reasons for acting on the conclusion. This process involves inference; "inference is a process by which one proposition is arrived at and affirmed on the basis of one or more other propositions accepted as the starting point of the process." 3

The logician examines propositions to see whether an inference is correct. To say that reasoning is logical is to claim that there is a correct process of inference that the premises enunciated correctly warrant the attendant conclusions. For example: all animals are mortal; all humans are animals; therefore, all humans are mortal.

\subsection{Is Legal Reasoning Logical?}

Some claim that legal reasoning is not logical, that it is nothing more than a smoke screen for a political discussion. This is John Griffith's position in his Politics of the Judiciary. We cannot deny altogether that lawyers have a pattern of reasoning since logic deals with patterns of rational thought. Most of the time we hear some say 'stop your hair-splitting legal argument'; 'you are arguing like a lawyer'. The point is that we cannot deny that lawyers have a pattern of argument; we shall concentrate on the form rather than on the content of their reasoning. Thus, in examining the form of their reasoning, we can determine whether legal reasoning is logical. With regard to form, legal reasoning can either be taken to be deductive or inductive. Ordinarily, every argument involves a claim that its premises provide some grounds for the truth of its conclusions.

Against this background, a deductive argument involves a claim that its premises provide conclusive grounds for its conclusion. A correct reasoning in a deductive argument is said to be valid; it is invalid when it is incorrect, meaning that the claim it makes about its conclusive ground provided by its premises is not the case. Deductive inferences move from general to particular: an example of a deductive argument is: all humans are mortal; Socrates is human; therefore, Socrates is mortal. There is here a logical necessary conclusion (Socrates is mortal) that is drawn from the major premise (all humans are mortal) and the minor premise (Socrates is human).

On the other hand, an inductive argument claims that its premises provide some support for the conclusion drawn from its premises. For example: "Hitler was a dictator and was ruthless; Stalin was a dictator and was ruthless; Raul Castro is a dictator; therefore, Raul Castro is probably ruthless." The major difference between a deductive argument and an inductive argument is not so much that the former moves from general to particular and the later from particular to general because an inductive argument may have particular as well as universal propositions for its premises. I. M. Copi and C. Cohen articulated the precise difference between a deductive and an inductive argument stating that:

The strength of the claim about the relation between the premises and the conclusion of the argument is the nub of the difference between deductive and inductive arguments. We characterize the two types of arguments as follows: A deductive argument is one whose conclusion is claimed to follow from its premises with absolute necessity, this necessity not being a matter of degree and not depending in any way upon whatever else may be the case; in sharp contrast, an inductive argument is one whose conclusion is claimed to follow from its premises only with probability, this probability being a 
matter of degree and dependent upon what else may be the case. ${ }^{1}$

Inductive reasoning is arrived at after collection and sorting of data. And the probable conclusion drawn from its premises can take off from the general or particular claims of such premises. What character do legal arguments have? Deductive and inductive reasoning have been considered to characterize legal arguments. These characteristics however are met with doubts in reference to legal reasoning which holds true of factual propositions, it does not hold true between norms. Even in clear cases, it is inappropriate to apply deductive reasoning. ${ }^{2}$ Hume has demonstrated that factual propositions are not available in normative terms. ${ }^{3}$ The tool in legal argument is the use of words; and such words are not instruments of mathematical precision. Thus, logical reasoning would not be useful in the resolution of legal problems or human affairs. One recalls that Hart has stated that words have 'open-texture' hence the penumbra area of doubt do not give the Judge pre-determined answers; and where alternative answers are available as in hard cases (where a Judge has discretion), ${ }^{4}$ logical reasoning becomes less useful.

Inductive reasoning is also rejected as characterizing legal arguments. Inductive reasoning claims that particular cases are examined from which general propositions are enunciated. Certainly Judges survey data of cases and produce rulings, which may cover a majority of cases, embodiments of particular ones. Each case presents a novelty and it is sometimes difficult to produce general conditions for all cases derived from particular instances of hard and clear cases, for "more than one answer may be given and supported by reference to 'the law". ${ }^{5}$ Some prefer to refer to legal reasoning as reasoning by example or analogy. In deciding the present case, Judges see how closely analogous it is to decide or to the hypothetical example implicit in a statute. The problem here, as indicated by J. W. Harris, is that the Judge does not state the reasons of substance that justify choosing between competing analogies. ${ }^{6}$

\section{6 "Does Legal Reasoning then throw Logic away"?}

On the whole, it is difficult to characterize legal reason as strictly deductive, inductive or analogical. Although the description of judicial reasoning/style is shrouded in obscurity; whatever it is, such reasoning does not necessarily throw logic away.

There is some degree of common "normative expectation held by the bench and bar as to what constitutes relevant and acceptable argument at law upon a given point, that facts already mentioned would lead one to infer that there are shared norms among judges and as between judges and counsel which determine what types of arguments do and ought to carry weight in contested matters of litigation. There is indeed within every legal system, and within the same one at different points of time, an observable common style of argumentation." 7 There is no doubt that there will be a noticeable difference of style among men and women of the bench, the fact remains that this is observable, though varied styles, that constitutes acceptable argument in the judicial process. Even where a judge has discretion or choice to decide either side, he has to give reason for so deciding and the law can distinguish between good and bad reasoning/argumentation.

Thus, judicial argumentation has also reference to the "kind of argument which the court will see good grounds to adopt, doubtless with modifications, as a strong or compelling reason for a decision in favor of that side." ${ }^{8}$ So, although judicial reasoning is a form of public argumentation, MacCormick insists that it is an activity conducted within more or less vague or clear implicit, or explicit, normative canons:

We distinguish between good and bad, sounder and less sound, relevant and irrelevant, acceptable or unacceptable arguments in relation to philosophical, economic, sociological, or, above all, legal disputation over given foci of dispute. That is possible only given some criteria ........... of goodness or badness, more or less soundness, relevancy, acceptability, and so forth. At the most superficial level, criteria of acceptable modes of presentation are also in play, and observance of these is in some measure determinative of style. ${ }^{9}$

It is in this regard that MacCormick sees any study of legal reasoning as an attempt to explain the criteria as to what constitutes a good or bad, acceptable or an unacceptable type of argument in law.

\subsection{What then is the Function of Legal Argumentation?}

Judges engage in making judgments about human affairs; hence their activity takes place in a practical context.

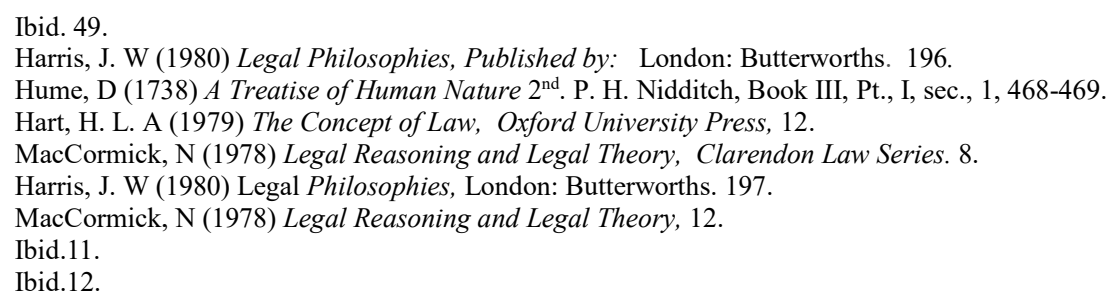


Some claim that arguments, in practical contexts, are meant to persuade. The ancient philosophical origin of persuasion in political and practical contexts is well known. It dates back to the Sophists of ancient Greece who maintained that to function well in practical life one needed the art of rhetoric in order to win people to one's side; hence arguments in practical contexts are advanced to persuade - one persuades an audience to do something.

Aristotle sees rhetoric as the art of persuasion; and persuasion is a sort of demonstration one exhibits when one is speaking:

For of the three elements in speech-making - speaker, subject, and the person addressed - it is the last one, the hearer, that determines the speech's end and object. The hearer must either be a Judge, with a decision to make about things past or future, or an observer. A member of the assembly decides about future events, a juryman about past events (while those who merely decide on the orator's skill are observers).From this it follows that there are three divisions of oratory - deliberative, forensic, and epideictic. Deliberative speaking urges us either to do or not to do something: one of these two courses is always taken by private counselors, as well as by men who address public assemblies. Forensic speaking either attacks or defends somebody: one or either of these two things must always be done by the parties in a case. Epideictic oratory either praises or censures somebody. These three kinds of rhetoric refer to three different kinds of time. The deliberative is concerned with future: it is about things to be done hereafter that he advises, for or against. The party in case at law is concerned with the past: one man accuses the other, and the other defends himself, with reference to things already done. The epideictic orator is, properly speaking, concerned with the present, since all men praise or blame in view of the state of things existing at the time, though they often find it useful also to recall the past and to make guesses at the future. ${ }^{l}$

Thus, lawyers' arguments are aimed at persuading Judges and jury trials, and appeals before higher courts have advocates whose main aim is to persuade the court or tribunal to decide in favor of their own side. Furthermore, underneath the practical aim of persuasion, people are making claims in law/court - they want to justify their claim or demonstrate that they have a justification for the damage they are suing for. As MacCormick writes:

If a citizen brings an action against another for example claiming damages for some alleged injury inflicted by the other, it is a logical conclusion of the success of his claim that he be able to show that it is a justified claim; if the other party denies liability, he must in his turn demonstrate that the claim is not justified and accordingly his demand to be absolved from liability is a justified demand. ${ }^{2}$

Sometimes people notice aberrations in the judicial system. A lawyer may try to persuade a Judge that a claim, he himself does not regard as sound, is nonetheless justified in law. In this case, the lawyer is insincere. However, a lawyer may be insincere, but for him to convince the Judge to decide in his favor, he has to give his reasons, and his insincerity will be revealed in the reasons he might give. There are cannons for addressing what constitutes good reason in law. Some reasons are not acceptable within the sustaining claims at law:

Whether sincerity advanced or not, only those arguments which show why $x$ ought to be done are reasons for demanding that it be done, or doing it. Those who works within such a system persuade precisely by convincing the relevant audience that there are reasons of overriding weight why $x$ ought to be done; or at least, by showing that are good ostensibly justifying reasons in addition to such other elements in the case as may appeal to unstated prejudices and predispositions. $^{3}$

On the whole, the essential notion in the function of legal argumentation is that of giving good justifying reasons for claims, defenses or decisions; hence MacCormick proposes that it is most rewarding to study the process of legal argumentation as a process of justification. The process of legal argumentation is sought to justify the position one is arguing for by the advocate or client; this process, seen from the Judge's perspective, is

Aristotle, (2017) Rhetoric, Oxford Handbook of Rhetorical Studies. Edited by: MacDonald, M. J. Bk., 1, Chap.3.1358b1-15.

MacCormick, N (1978) Legal Reasoning and Legal Theory, 14.

Ibid.15. 
a process of discovery. One might say that legally justifying reasons are so vague and inadequate, and a judge can be prompted to decide one way rather than the other. Therefore, the so-called justifying reasons in law never function as more than ostensibly justifying reasons operating to cloak decisions always motivated by other forces. However, it has to be noted that there are strong social pressures on Judges to present themselves as arbiters of justice: "Judges present themselves as the impartial determiners of disputes between citizens, or of prosecutions by public authorities of citizens. They so present themselves at least because within the dominant political tradition that is what they are expected to be. They are appointed to do justice according to law, and the watchdogs of the public interest are continually alert to yap at their heels if they appear to do any other thing." So what does the Judge sit there to do when claims and counter-claims are made before him/her? He/she is there to listen and discover the truth, or as in Ronald Dworkin's understanding, to enforce existing rights which litigants have. ${ }^{2}$

We have indicated that Dworkin has argued that Judges are there to enforce existing institutional rights, that is, to discover who has right. Therefore, there is an effective pressure on Judges to appear to be what they are expected to be. In other words;

The reasons they publicly state for their decisions must therefore be reasons which (so far as taken seriously) make them appear to be what they are supposed to be: in short, reasons which show that their decisions secure 'justice according to law', and which are at least in that sense justifying reasons. Equally, therefore, lawyers who want to win their cases are on notice that they had better give reasons on behalf of their clients, this could consistently, with the required appearances, commend themselves to the judiciary. In short, justifying reasons. ${ }^{3}$

Sometimes Lawyers and Judges are said to take bribes so as to tilt the scale of justice to the favor of the highest bidder. The common man in Nigeria, for example, may be reluctant to seek justice in court for he fears he may not succeed, since he may have to pay a bribe to a Judge so as to influence his/her decision. The ordinary poor man in Nigeria is actually entitled to his feeling which may or may not be founded; it could be that he does not know or understand how Judges' decisions are arrived at or how the adjudicating process functions, or how evidences are evaluated to conspire to favor a decision in one direction rather than the other.

In the absence of concrete evidence to prove a particular event, which may have truly happened, the Judge may dismiss a case as having no sufficient grounds to be pursued in court; this state of affairs may be shocking to a layperson who really knows that the accused was truly responsible for the alleged offence. There is no doubt that evidence plus evidence may not be equal to truth. No doubt H. L. A. Hart intimates that a Judge's decision is a performance and not reducible to truth conditions; hence it had to be understood within the legal context. Legal judgments are not necessarily co-extensive with extra-legal facts. However, in spite of the presentiment one may have about the court's decision, "it seems reasonable to suppose that Judges and Lawyers are, like all humans, capable of occasional fits of humbug and hypocrisy, or of interpreting rooted prejudices as revealed truths.

But equally, they are more commonly honest and honorable, capable of real efforts at, if never total achievement of, impartiality and objectivity; through practice, moreover, they have normally done more to develop habits of impartiality than many of those who are most strident in their denunciation." ${ }^{4}$ Judges are trained to render justice and be impartial in the system in which they are administering.

But it is a different question whether the system in which they are operating is systematically impartial or just. The point is, as H. L. A. Hart would claim, that a Judge has to treat like cases alike. A Judge would be acting at once legally and immorally if he denies one the justice recognized by the law or the legal system. The evaluation of the justice or morality of the whole system belongs to a different level of questioning or investigation, which legislators and citizens alike will have to face, whenever they want to make laws to govern them, and assess the impact of the laws on their lives. The justice or morality of applying valid rules/laws is not necessarily identical with the claim that the legal system as a whole is morally worthwhile. People must continue to have a moral scrutiny of their legal system to see how it conforms to general principles of morality. By applying the rules, even if principles and policies are part of the institutional rules, a Judge in doing his duty does not necessarily certify the morality of the system he is administering.

By applying the rules, even if principles and policies are part of the institutional rules, a Judge in doing his duty does not necessarily attest to the morality of the system he is administering. Hence, as H. L. A. Hart makes this point very clear, when he states:

So long as human beings can gain sufficient co-operation from some to enable

them to dominate others, they will use the forms of law as one of their instruments.

Wicked men will enact wicked rules, which others will enforce. What surely is

MacCormick, N (1978) Legal Reasoning and Legal Theory, 17.

Dworkin, R (1977) Taking Rights Seriously (New Impressions with a Reply to Critics), 87. Harvard University Press.

Ibid.

Ibid. 17 
most needed in order to make men clear sighted in confronting the official abuse of power, is that they should preserve the sense that the certification of something as legally valid is not conclusive of the question of obedience, and that, however great the aura of majesty or authority which the official system may have, its demands must in the end be submitted to a moral scrutiny. ${ }^{1}$

\subsection{Conclusion}

A Judge, sitting and listening, tries to discover grounds that constitute good and justifying reasons as led down by the law. The moral justification for legal reasoning and rights of people within the system might be independent of the legal reasons given for their recognition. From the academic perspective, scholars are still divided as to whether reason or emotion greatly dominates the process of adjudication. The process of adjudication is termed legal 'logic'. Not many, however, will accept that logic has a place in the process of adjudication. Most theorists claim that deductive and inductive reasoning play only a subordinate role in the adjudicative process.

Some jurists insist that the life of law has not been logic but experience (Holmes). Others go at length to affirm that decisions of courts are essentially arbitrary. Hart, however, refutes the view that judicial decisions are arbitrary, especially decisions of cases which cannot be exhibited as deductions from determinate legal rules. He thinks that this charge is misleading in the sense that it misrepresents the horizon of indeterminacy of rules.

Judges decide cases within the context of operation of rules in which multiple considerations are taken on board before one adopts what is taken to be a good reason for a decision. There are many individual, social, political and moral interests that come into play in the formation of a judge's decision. While some theorists claim that an indeterminate answer could be reached in giving judgment; some others claim that there is always a right answer; and the judge tries to find the answer. But how fair is this judge's decision in a system that applies precedent? There is then some doubt cast on the so-called fairness of judicial decisions. In the practice of precedent, a judge bases a present decision about a case on the principles established in a previous case. If every case presents its own novelty, it becomes very limited to be determined in a present case by past decisions.

\section{References}

Barnes, J (1982) 'Aristotle' (Oxford: Oxford University Press).

Copi I. M \& Cohen, C (1990) Introduction to Logic 8d. (New York: Macmillan Publishing Company).

Dworkin, R (1977) Taking Rights Seriously (New Impressions with a Reply to Critics), 87. Harvard University Press.

Finnis, J (1980) 'Natural Law and Natural Rights'. Oxford: Oxford University Press.

Hart, H. L. A (1979) 'The Concept of Law', Oxford University Press.

Harris, J. W (1980) Legal Philosophies, London: Butterworths.

Hobbes, T. (1968) 'Leviathan', ed., C. B. MacPherson. London: Penguin Books Publishing.

Hume, D. A (1978) 'Treatise on Human Nature' 2d. P. H. Nidditch (Oxford University Press.

MacCormick, N (1978) 'Legal Reasoning and Legal Theory' (Oxford: Clarendon Press Oxford).

Mandeville, B. (MDCCCCXXIV) 'The Fable of the Bees or Private Vices, Public Benefits', ed. F. B. Kaye, Vol. 2 Oxford: Clarendon Press.

Schneewind, J. B (1990) ed., 'Moral Philosophy from Montaigne to Kent: An Antology' (Cambridge: Cambridge University Press), Vol. 1, 277-279.

Shaftesbury, A. E (MDCCXC) 'Characters of Men, Manners, Opinions, Times with a Collection of Letters', Vol. 2 (Legrand), 23.

Reid, T (1983) Inquiry and Essays eds. Ronald E. Beanblossom and Keith Lehrer (Indianapolis: Hackett Publishing Company, Inc.,), 152. 